\title{
Black Spectral Lives Matter
}

\author{
Tori Omega Arthur
}

Miles, Tiya. Tales from the Haunted South: dark tourism and memories of slavery from the Civil-War era. Chapel Hill: The University of North Carolina Press, 2015. 176 p.

Over the last few years, the United States has witnessed the rise of a collective of individuals working together to shed light on the ongoing struggles with racism and violence in the nation. In the wake of the deaths and brutalization of several people, the Black Lives Matter movement has sought to make clear that the residual affects of the transatlantic trading of Africans and racist oppression of black people still have a place within American society and culture. The election of Barack Obama as the first black President of the United States did not render racism dead. Issues of race and racism have arguably been more visible and acute because of the Obama family's historic occupation of the White House. In Tales from the Haunted South, Tiya Miles takes up the painful histories of enslaved black bodies in the United States and the spectral occupations of various houses in the South to interrogate a phenomenon that has virtually erased the atrocities of slavery and existences of those forced into the system of enslavement.

Miles explores the increasingly popular sensation of ghost tourism in the American South where tourists descend upon certain locations in search of the spirits supposedly inhabiting them. Each year, thousands of thrill seeking ghost hunters hoping to encounter ornery apparitions and suffering specters flock to plantations, cemeteries and burial grounds, and historic urban houses in Georgia, South Carolina, and Louisiana and are ushered into supernatural dream worlds supposedly teeming with long dead enslaved blacks. While this form of tourism may seem like an innocuous enterprise catered to those who find fun in being scared, Miles reveals that the stories routinely accompanying ghost tours misappropriate African American history for commercial gain. Tourists purchase tour tickets and even pay to stay in the homes overnight hoping to (or not hoping to) see ghosts. Subsequently, the horrors that many enslaved blacks endured, particularly enslaved black women who were victims of sexual oppression, are reinterpreted to elide the true nature of slavery and the Civil War era.

Fellow in Ethnic Studies at Lawrence University in Appleton, Wisconsin 
Employing her personal experiences touring supposedly haunted sites, Miles examines the ghost narratives at three southern locations to discern how the lives and afterlives of enslaved blacks are presented to the public. Miles devotes chapters to: 1) Molly and Matilda of the Sorrel-Weed House in Savannah, Georgia; 2) Madame Delphine Lalaurie's barbaric treatment of those enslaved in her Royal Street mansion in the French Quarter of New Orleans, Louisiana; and, 3) Chloe and Cleo of the Myrtles Plantation in St. Francisville, Louisiana. Each of these three substantive chapters unpacks the facts and fictions of the locations and the people who lived there during the antebellum period in United States history. Miles argues that these ghost tours and others throughout the South catalogue disturbing events of the past that have been eliminated from America's collective and conscious social memory, leaving behind mere fragments of the actual brutal lives of the formerly enslaved that are rationalized away and dismissed as unbelievable. What is real about these ghost tours is the sheer power of supernatural accounts to bolster a commercial industry. Miles makes clear that just as the lives of black enslaved people existed to increase the profits of their white owners, black spectral lives in modern day ghost tourism support the money making efforts of the mostly white owned businesses conducting the tours.

The major strength of the text is Miles's evocative writing. With a combination of a creative nonfiction style (I was not surprised to learn that Miles has published a novel.) and auto-ethnography, Miles literarily weaves the tales of the sites she visits with their history and her keen historical analysis. Her investigation of the Sorrel-Weed House and the story of the enslaved Haitian girl Molly's sexual relationship with owner Francis Sorrel and her mysterious hanging after the suicide of Sorrel's wife Matilda is in depth and fascinating. Molly and the Sorrel-Weed House are the backbone of the book. It is with this story that Miles's curiosity with the machinations of ghost tourism as a money making industry truly begins. Miles deftly shows that Molly's plight as an enslaved black woman locked in a brutal institution where her humanity and personal agency were routinely denied becomes a metaphor for how America feels about race and black people. Molly is a side show, an exotic spectacle whose existence during her life and afterlife is jeered and eventually discarded.

Another strength of the book is the notes section. Much of the academic muscle of the text is in the roughly forty-five pages of notes accompanying the primary narratives. The notes section offers additional analysis and a rich resource of texts where readers can acquire more information about America's antebellum history, race and gender in the South during the Civil War era, and the role of tourism in 
American society. Also, in the notes, Miles informs the reader that she has opted not to emphasize theory in Tales from the Haunted South. Certainly, in this book where the author's personal experiences with ghost tours and the stories of the places she visits are most engaging, an overemphasis on theory would have made Miles's text pedantic and inaccessible to some readers. Instead, Miles has offered a highly accessible text that would be of interest to scholars, students, and those in the general public around the world with an interest in the histories of the American South and the Civil War and with transnational issues of race, racism, and the legacies of the transatlantic slavery in the black diaspora.

While Miles's evocative and often lyrical writing are strong, the text becomes repetitious at times. In chapters two and three where the reader learns of Madame Lalaurie, Chloe, and Cleo in Louisiana, the narratives fall under the weight of repetition. There, the writing is a bit strained in places (except in chapter three when Miles poignantly discusses the nuances of race, gender, and sexuality in a gay black male's tour of the Myrtles) and feels as if the author is trying to fill pages with words to make the manuscript book length. This strain is also apparent in the conclusion when Miles incorporates her experiences with African American heritage tours in the South. Though she briefly argues that these tours serve as a counterpoint to ghostly tales of sex and death, the analysis feels misplaced and would perhaps be better suited in another text that gives adequate space to the subversive work the people conducting these heritage tours are doing to include a more thorough view of African American life and culture during and beyond slavery in Southern history and overall American history for the touring public.

Perhaps the book's biggest misstep is the conflation of ghost tourism with dark tourism through much of the text. Though they are not synonymous, Miles offers cursory definitions of dark tourism and ghost tourism in the introduction and the two terms appear interchangeably through the major chapters. In the introduction, she defines dark tourism as "the exploration of death, disaster, and suffering through travel." (p. 10) Readers who are unfamiliar with key terms and concepts in tourism studies may not understand that while ghost tourism is a form of dark tourism, dark tourism is much more than ghost tourism and can consist of touring battlegrounds, prisons, concentration camps and other sites of massacres or genocide, sites of natural and man made disasters, etc. In the conclusion, Miles devotes time to a more in depth discussion of dark tourism that would have fit well with the overview given in the introduction. However, her focus on explaining the allure of ghost stories and tours is understandable considering that the tours result in the erasure of the lives of the black 'ghosts' in each location. The title 
of the book could easily be Tales from the Haunted South: Ghost Tourism and Memories of Slavery from the Civil War Era.

Overall, Miles's book is a necessary inclusion in the study of black cultural tourism, which is a growing field of academic inquiry. In the last two decades, much of the work in black cultural tourism has focused on tourism as reclamation or the efforts of black travelers to visit important historical sites as a way of engaging with black history in the United States and abroad. Scholars like Kamari Maxine Clarke, Paulla A. Ebron, Saidiyah Hartman, and others have produced work that explores the experiences of African American descendants of the formerly enslaved traveling to the African continent to reconnect (or not) with their ancestral home. However, Tales from the Haunted South is a departure from this academic movement. Instead of focusing on the black traveler experience, Miles hones in on how specific sites that hold places in the global histories of slavery and the black people who once occupied and may still occupy those sites are commercialized for largely non-black travelers seeking to consume the exotic and invisible 'other.'

As stated, the text would be of interest to students, scholars, and the general public who (professionally and leisurely) study the American South, slavery, and the Civil War. For Brazilian readers, the book offers a comparative opportunity; those desiring to examine the parallel histories of slavery and the ways black people are remembered would be able to compare the racial traditions of Brazil and the United States. Indeed, the book should have a place on the shelf of anyone invested in uncovering the tragic accounts of enslaved blacks throughout the black diaspora whose lives and afterlives are devalued and/or commodified. Miles makes clear that these practices should be questioned not just for historical veracity, but also for their power to negate black lives in the past, present, and future. As scholars, artists, activists, and others continue to expose the contrivances of race and racism in the United States and around the world, the stories and arguments in Miles's captivating text remind us that not only do black lives matter, black spectral lives matter and should be honored and respected for the role they play in ensuring that black life, history, and culture is never forgotten.

Recebido para publicação em: 25/08/2016. Aceito para publicação em: 16/09/2016. 